\title{
Seeking a consensus: water management principles from the monotheistic scriptures
}

\author{
Ryan Lefers ${ }^{\mathrm{a}}$, Robert G. Maliva ${ }^{\mathrm{b}}$ and Thomas M. Missimer ${ }^{\mathrm{c}}$ \\ ${ }^{a}$ King Abdullah University of Science and Technology (KAUST), Water Desalination and Reuse Center, Thuwul 23955-6900, \\ Saudi Arabia \\ ${ }^{b}$ Schlumberger Water Services, 1567 Hayley Land, Suite 202, Fort Myers, FL 33091, USA \\ ${ }^{c}$ Corresponding author. U.A. Whitaker College of Engineering, Florida Gulf Coast University, 10501 FGCU Boulevard North,
} Fort Myers, FL 33965-6565, USA. E-mail: tmissimer@fgcu.edu

\begin{abstract}
Religious and cultural values related to water use and management are important motivation for many people of the world. Although much has been written related to water management and use in Islam, fewer authors have attempted to evaluate water management through the lens of other religions. The common thread of monotheism, specifically worship of the one God of Abraham, binds together the world's largest two religions (Islam and Christianity). Judaism also falls within this monotheistic group and is especially important in the context of Middle Eastern water management. As agriculture consumes approximately $70 \%$ of all fresh water used in the world today, proper management of water within its context is of critical and global importance. This paper presents an effort to build consensus from a monotheistic scripture-based perspective related to water management in agriculture. If greater dialog and agreement about water management can be attained within and among monotheists, complex issues related to transboundary water management, reuse and conservation could be resolved with less conflict, creating a shared overall management vision.
\end{abstract}

Keywords: Agricultural water; Conservation; Ethics; Monotheism; Transboundary water; Water and religion; Water management; Water policy; Water value

\section{Introduction}

Water policy and management plans and decisions are not solely governed by technical issues, but also by economic and cultural factors that affect people. Much has been written about water management from a technical perspective. Indeed, there are scientists and engineers of many races, creeds, and nationalities that have come to some consensus related to the basics of water management and its value related to life on earth from a purely scientific perspective. However, for many people doi: 10.2166/wp.2015.165

C IWA Publishing 2015 
inhabiting the world today, religious teachings play a fundamental motivational role in every day decisions; sometimes over and above scientific or technical advice given by academics and consultants or learned through various media and educational outlets. Therefore, religious texts which guide an individual's daily behavior have the potential to support or disagree with decisions related to the natural world, particularly with regard to all aspects involving water or food (Coward, 2003; Mieth, 2010; Chuvieco, 2012). Water management plans developed without consideration of cultural and religious beliefs are doomed to failure in many parts of the world.

Christianity claims the largest overall percent of adherents in the world today, at around $33 \%$ based on 2010 estimates of the US Central Intelligence Agency (CIA, 2013). Islam is the second largest religious block in the world, at around 23\%, again based on 2010 estimates (CIA, 2013). Put together, these two religions account for over half $(56 \%)$ of all humans living on the planet today. Therefore, seeking consensus related to any topic of importance between these two religions would seem an important and worthwhile task. Although Judaism claims a much lower percentage $(0.22 \%)$ of total world adherents (CIA, 2013), attempting to find a consensus among fundamental texts of Judaism, Islam, and Christianity would be of great value in areas such as the Middle East, where monotheists are the population norm and fresh water resources are scarce.

Various researchers have attempted to weave a religious or cultural dynamic into their assessments of local or global water or environmental management strategies. In a survey completed in the West Bank (Palestine), respondents said that technical experts must work closely and cooperate with the religious references regarding water reuse (Al-Kharouf et al., 2008). Al-Weshah suggested that agricultural water management practices in Jordan Valley are based on biblically founded attitudes (Al-Weshah, 2000). Traditional Zionism greatly values agriculture and therefore agricultural water use (Lipchin, 2007a, 2007b). Hillel (2005) looked at ways the surrounding environment impacted Judaism. Priscoli (2012) includes quotes from a number of Christian leaders and historical figures in his evaluation of the water resource decision nexus. Siler (2008) discussed approaches to water management in the monotheistic religions, with a focus on Islam. Compared with the other monotheistic faiths, much has been written on water management from a purely Islamic perspective (Abderrahman, 2000; Amery, 2001; Faruqui et al., 2001; Bin Muhammad et al., 2010; Haddad, 2012). Naff \& Dellapenna (2002) evaluated the consensus between secular water law and Islamic water law. Other authors have attempted to put together religious views of water and its management from the perspective of multiple religions (Coward, 2003; Chuvieco, 2012; Maliva \& Missimer, 2012; Wolf, 2012). A consensus-seeking review of monotheistic texts related to agricultural water management (or water management in general) was not found during a literature review for this research.

In 2007, the 'A Common Word Between Us and You' letter, originating from and signed by 138 leaders within the world Islamic community, was published online as an open call to other 'People of the Book' (i.e., other monotheists who follow the sacred scriptures) and with a special direction toward Christians (The Royal Aal al-Bayt Institute for Islamic Thought, 2007). The Common Word letter had its foundation based upon the following verse from the Qur' an ${ }^{1}$ :

\footnotetext{
${ }^{1}$ All Qur'an quotes taken from The Arabic-English Reference Qur'an, First Edition, The Reference Qur'an Council, (C July, 2013 (The Arabic-English Reference Qur'an, 2013).
} 
People of the book, come to a common word between us and you that we won't worship any other gods besides Allah, and we will not make anything else a god, nor will we take each other as gods in addition to Allah. If they turn away, say, 'Testify that we have submitted.' (Qur'an, Al-'Imran 3:64)

The letter was intended to call monotheistic adherents to a 'common word' upon which peaceful and meaningful dialog could take place among the monotheistic religions. It focused on coming to a consensus regarding the two great commandments: love God and love your neighbor. Since release of the letter in 2007, a number of interfaith dialogs on various topics have taken place in the same spirit of consensus seeking. The idea of coming to a 'common word' on topics outside of the worship of and unity of God are addressed in the middle part of the above verse '.......nor will we take each other as gods in addition to Allah.' The meaning of this phrase, according to a leading commentary (tafsir) on the Qur'an (the Jami' Al-Bayan fi Ta'wil Al-Qur'an of Abu Ja'far Muhammad bin Jarir Al-Tabari) is 'that none of us should obey [another authority] in disobedience to what God has commanded...' (The Royal Aal al-Bayt Institute for Islamic Thought, 2007). To put it another way, monotheists (Muslims, Christians, and Jews) must obey God's directions and commandments on relevant topics over and above their own national traditions, laws, and/or local cultural norms. Of course, not all professed monotheists in the world today are practicing, therefore obedience to directions and commands from scripture will vary based on the individual.

In 2008, 'The Makka Declaration' was released at the close of the World Islamic Conference on Dialog. The conference identified one of its main topics for interfaith dialog as: 'Causing damage to the environment, and dealing with any harm done or expected to be done against it, in order to avoid widespread dangers and disasters against all of humanity' (The Makkah Declaration, 2008). The environment was selected as an important topic for dialog based upon a verse from the Qur'an.

Don't cause destruction in the earth after it has been made right. Pray to him in fear and desire. Allah's mercy is near to those who do good. (Qur'an, Al-A'raf 7:56)

Faith-based consensus on environmental issues continued to garner attention in the international scene. The idea of coming to a consensus related to the environment was explored at a special symposium in September of 2010 entitled 'The Royal Aal Al-Bayt Institute for Islamic Thought Environment Symposium.' Relevant proceedings from this symposium (Bin Muhammad et al., 2010; Mattson, 2010; Mieth, 2010) were reviewed as part of this work. In 2012, the King Abdullah Bin Abdulaziz International Center For Interreligious and Intercultural Dialog was established by the three Founding States of the Kingdom of Saudi Arabia, the Republic of Austria, and the Kingdom of Spain. The Center has in its charter that a primary objective will be to 'address the contemporary challenges to society, such as.... preservation of the environment, sustainable use of natural resources,..' (Objectives and Activities, Article II, 1, (d)), (KAICIID, 2012).

Because all three religions (Islam, Christianity, and Judaism) have numerous sects and leaders of sects, it is difficult, if not impossible, to come to a complete consensus on every topic of importance. This is true both within the religions (for example: Shi' a vs. Sunni in Islam; Catholic vs. Protestant vs. Orthodox in Christianity; Orthodox vs. Conservative vs. Reform in Judaism; etc.) as well as among the religions. Each group or subgroup often has its own revered scholars, publications, interpretations, and traditions built up over years and centuries. While there may be commonalities among these traditions, it will be more difficult to recognize and apply commonalities gleaned from texts that are important to 
only a specific subgroup of the larger group of monotheists. Therefore, if a large consensus is sought, it is imperative to review what is most common and shared among the various sects and subgroups: namely the fundamental scriptures upon which the great religions themselves are based and which are perceived by adherents to be the inspired words of God himself (as opposed to a human text, interpretation, or tradition added upon these scriptures). The fundamental scriptures of monotheists are the Qur'an and the Bible. The word Qur'an in English is a direct transliteration of the Arabic and literally means 'recitation.' The word Bible in English comes from the Greek plural of the word 'biblion', meaning 'books' (Merriam-Webster Online Dictionary, 2013). The Jewish 'biblion' collection is commonly called the Hebrew Bible or the Tanakh. Included in the Christian 'biblion' are the books of the 'Old Testament' (the Tanakh) and the 'New Testament.' Because the books of the Tanakh came first in time, various parts are identified and endorsed in both the Qur'an and the New Testament by names such as: the Torah, Books of Moses, Psalms (zabur in Qur'anic Arabic), the Wisdom (al-hikmah in Qur'anic Arabic), the books of the prophets, and the Law, among others. The New Testament is also referred to and endorsed in the Qur'an as: the Gospel (Injil in Qur'anic Arabic), the book that is in their (Christian's) hands, and the Book from before.

As it relates to water management and its importance in the global water context, the greatest potential for fresh water use in efficiency and savings is within agriculture. Agriculture is estimated to consume $70 \%$ of extracted fresh water worldwide (Pimentel et al., 2004). Although not often considered by the average consumer, it has been noted that we actually consume more fresh water through what we eat than what we drink. Approximately 1,000 liters of water are used to produce $1 \mathrm{~kg}$ of cereal grain and approximately 43,000 liters of water are used to produce $1 \mathrm{~kg}$ of beef (Pimentel et al., 2004). Therefore, farmer choices regarding crops grown as well as consumers' food choices have not only an economic and health benefit, but also a real impact on actual total water use in agriculture worldwide.

In this paper, an attempt is made to identify 'common words' from the monotheistic scriptures related to the origin and value of water as well as direct instructions for water use and its management. In the spirit of the Common Word letter, an attempt is made to identify and build upon commonalities among the scriptures, where they may exist. A monotheistic scripture consensus will be sought that lays the foundation for personal and community decision-making regarding water and its use in general and agricultural contexts. This common consensus issue is particularly acute when dealing with transboundary disputes between countries with two or more of the monotheistic faiths involved.

\section{Methodology}

An extensive search of the scriptures was conducted to find, assess, and document the influence and potential influence of these texts on water management and use. The practices and principles found in the monotheistic scriptures regarding water management were compiled to assess commonalities for the purpose of drawing attention to those that could assist scientists and engineers in developing culturallyacceptable policies.

Some readers may question why only the scriptures were reviewed for this effort and not additional religious texts or traditions. That texts and traditions such as those found in the Hadith, Talmud and similar are valued by adherents is beyond question. However, how much these texts (outside of the scriptures) are valued by individual sects and adherents within the religions varies widely. The goal of this paper is not to develop water management guidelines for each narrow subsect (that is up to 
the adherents within each group). The goal is rather to develop a baseline (common word) for water management that can be widely discussed both within and among monotheists because it is based on texts (the monotheistic scriptures) that are widely accepted by the greater group of monotheists.

\section{The origin of water in monotheistic literature}

The origin and importance of water in the scriptures of the monotheistic faiths points to a value beyond economics. In the Genesis ${ }^{2}$ account of the creation of the world, we find that water is the first form of matter.

Genesis 1: 1-2 'In the beginning God created the heavens and the earth. Now the earth was without shape and empty, and darkness was over the surface of the watery deep, but the Spirit of God was moving over the surface of the water. (Tanakh, Genesis 1:1-2)

In the following acts of creation, we again see water taking a central role. After the creation of light, the second and third days of creation are occupied with perfecting the form and place of water.

God said, 'Let there be light.' And there was light! God saw that the light was good, so God separated the light from the darkness. God called the light 'day' and the darkness 'night.' There was evening, and there was morning, marking the first day. God said, 'Let there be an expanse in the midst of the waters and let it separate water from water.' So God made the expanse and separated the water under the expanse from the water above it. It was so. God called the expanse 'sky.' There was evening, and there was morning, a second day. God said, 'Let the water under the sky be gathered to one place and let dry ground appear.' It was so. God called the dry ground 'land' and the gathered waters he called 'seas.' God saw that it was good. (Tanakh, Genesis 1:3-10)

An observation from these verses is that mankind mimics water processes carried out during these 2 days of creation. Man also separates 'water from water' in processes such as wastewater treatment and desalination. Man attempts to keep water 'gathered' so that 'dry ground [will] appear' in flood prevention measures like dams and flood channels, agricultural tile drainage, and the like. A monotheist could perhaps say that water engineering had its foundation at the creation of the world and has been continuing until now.

The Qur'an confirms the ideas of water being the first form of matter to exist and of God 'splitting' water during the creation.

Do disbelievers not know that the heavens and the earth were one mass and we split them and made every living thing from water? Do they not believe? (Qur'an, Al-Anbiya' 21:30)

The scriptures are in agreement regarding the value of water as the first matter to exist and of the fact that God himself was the first one to separate and exercise control over water. This is the first point that monotheists can build upon as a 'common word.'

\footnotetext{
${ }^{2}$ Scripture quoted by permission. All scripture quotations, unless otherwise indicated, are taken from the NET Bible ${ }^{\circledR}$ copyright@ $1996-2006$ by Biblical Studies Press, L.L.C. All rights reserved. (NET Bible $\left.{ }^{\circledR}, 1996-2006\right)$
} 


\section{Spiritual comparisons with water}

Water has value for humans outside of just consumption and economic uses (Burmil et al., 1999). For monotheists, water is not just a material form of matter in this world. It has a value and form in the spiritual realm as well. In the Tanakh, water poured on 'thirsty land' is paralleled with God's spirit being poured on people.

For I [God] will pour water on the parched ground and cause streams to flow on the dry land. I will pour my spirit on your offspring and my blessing on your children. They will sprout up like a tree in the grass, like poplars beside channels of water. (Tanakh, Isaiah 44:3-4)

In the New Testament, Jesus also compares water with the spirit.

On the last day of the feast, the greatest day, Jesus stood up and shouted out, 'If anyone is thirsty, let him come to me, and let the one who believes in me drink. Just as the scripture says, 'From within him will flow rivers of living water." (Now he said this about the spirit, whom those who believed in him were going to receive, for the spirit had not yet been given, because Jesus was not yet glorified.) (New Testament, John 7:37-39)

Although it does not specifically refer to the spirit as 'living water,' the Qur'an agrees with the fact that a spirit from God (Ruh in Qur'anic Arabic) is an aid or providence for believers (Qur'an, Al-Mujādila 58:22), which could also be said about water. Interestingly, the promise of a heavenly garden with 'flowing rivers underneath' (i.e., water) is included in the same verse.

You will not find that people who believe in Allah and the last day also love those who oppose Allah and his messenger, even their fathers, sons, brothers, or relatives. Allah has written faith on their hearts and aided them with a spirit from him. He will admit them to heavenly gardens with flowing rivers underneath, where they will live forever. There Allah is pleased with them, and they are pleased with him. They are Allah's party. Is Allah's party not prosperous? (Qur'an, Al-Mujādila 58:22)

Again, the Qur'an makes reference to heaven as a place where water is abundantly available (Qur'an, Muhammad 47:15). Of note is that those who are in 'hellfire' are also given water, but of a state that is not suitable for consumption.

The heavenly garden the godly are promised is like rivers of clear water, rivers of unspoiled milk, rivers of delightful wine, and rivers of strained honey. There they will have all kinds of fruit and forgiveness from their Lord. Are they like those who are in hellfire forever, given boiling water to drink that tears out their intestines? (Qur'an, Muhammad 47:15)

Like in the Qur'an, good quality water is seen as a heavenly reward for righteous people, both in the Tanakh and in the New Testament.

The Lord is my shepherd, I lack nothing. He takes me to lush pastures he leads me to refreshing water. (Tanakh, Psalms 23:1-2) 
He also said to me, 'It is done! I am the Alpha and the Omega, the beginning and the end. To the one who is thirsty I will give water free of charge from the spring of the water of life.' (New Testament, Revelation 21:6)

Then the angel showed me the river of the water of life - water as clear as crystal-pouring out from the throne of God and of the Lamb [in heaven], (New Testament, Revelation 22:1)

And the Spirit and the bride say, 'Come!' And let the one who hears say: 'Come!' And let the one who is thirsty come; let the one who wants it take the water of life free of charge. (New Testament, Revelation 22:17)

In its physical form, water is a sign of spiritual repentance in baptism (New Testament, Mark 1:4, Luke 3:3, Acts 13:24, Acts 19:4). Water is also used in the Jewish rituals of washing hands (Tanakh, Psalms 26:6) and ritual washing for purification (Tanakh, Leviticus 14-17), and for purification before prayers in Islam (Qur'an Al-Ma'ida 5:6).

Clearly water has a higher form than just worldly and physical in monotheistic scriptures. Indeed, water is compared with God's spirit and heavenly water is a promise for the righteous. The second point that monotheists can agree on is that water has an intrinsically spiritual value and is a sign reminding humans of spiritual realities that are beyond the physical world. Therefore, great respect for the resource is an expected attitude that should prevail among monotheists in decisions regarding water use and consumption.

\section{Water for agriculture is a sign of god's blessing}

In the physical world, water provided for agriculture is a sign of God's blessing. We read in the Psalms

You visit the earth and give it rain; you make it rich and fertilewith overflowing streams full of water. You provide grain for them, for you prepare the earth to yield its crops. You saturate its furrows, and soak its plowed ground. With rain showers you soften its soil, and make its crops grow. You crown the year with your good blessings, and you leave abundance in your wake. The pastures in the wilderness glisten with moisture, and the hills are clothed with joy. The meadows are clothed with sheep, and the valleys are covered with grain. They shout joyfully, yes, they sing. (Tanakh, Psalms 65:9-13)

Again, in the Psalms we read

He turns springs into streams; they flow between the mountains. They provide water for all the animals in the field; the wild donkeys quench their thirst. The birds of the sky live beside them; they chirp among the bushes. He waters the mountains from the upper rooms of his palace; the earth is full of the fruit you cause to grow. He provides grass for the cattle, and crops for people to cultivate, so they can produce food from the ground. (Tanakh, Psalms 104:10-14)

Elsewhere in the Tanakh, we see again how God provides water for agriculture.

He does great and unsearchable things, marvelous things without number; he gives rain on the earth, and sends water on the fields...(Tanakh, Job 5:9-10) 
The Qur'an confirms that God sends water for agriculture and made the rivers (water) subject to man's control.

Allah is the creator of the heavens and the earth, and he sent down rain from the sky, brought forth fruits from it as provision for you, and made ships subject to you so they can travel on the sea by his command, and he made the rivers subject to you. (Qur'an, Ibrahim 14:32)

Again in the Qur'an we read

We sent down abundant water from the presses to make seeds and plants sprout, as well as thicklyplanted gardens. (Qur'an, Al-Naba' 78:14-16)

Let man look at his food. We poured out water, split the earth, and caused seeds to sprout in it, as well as grapes, clover, olives, palms, thick gardens, fruit and plants, as enjoyment for you and your cattle. (Qur'an, Abasa 80:24-32)

He [Allah] planted trellised and untrellised gardens, palm trees, and differing plants for food: olives, pomegranates, similar yet dissimilar. Eat their fruit when it ripens, and pay for it on harvest day. Do not waste it. He does not love wasters. (Qur'an, Al-An'am 6:141)

The monotheistic scriptures are in agreement regarding God's provision of water for agriculture. Thus, the third point that monotheists can agree on is that one of the roles of water as provided by God is for production agriculture. Water is given by God to produce provisions for man in the form of food.

\section{Mankind is a regent or steward of the earth}

There are a number of statements and rules regarding general environmental conservation in the monotheistic scriptures that can also be applied generally to water. In the Tanakh we read

God blessed them and said to them, 'Be fruitful and multiply! Fill the earth and subdue it! Rule over the fish of the sea and the birds of the air and every creature that moves on the ground.' (Tanakh, Genesis 1:28)

This single verse and the various interpretations of the original Hebrew word kaw-bash' (translated here as 'subdue') have been used to support a wide variety of views related to the environment. Other translations for kaw-bash' include: 'to subject, subdue, force, keep under, or bring into bondage' (Brown et al., 1906). Because of these wide translations, environmental views (particularly within Judaism and Christianity) tend to range widely between nature existing only for the sake of humans to humans being held critically responsible for the stewardship of nature (Maliva \& Missimer, 2012). However, the focus of this work is not to explore the why and how of these various interpretations, but rather to see how this scripture might come to a consensus with other monotheistic scriptures focused on water and its management.

One of the translations of the Hebrew word kaw-bash' that seems to fit in well with other monotheistic scriptures is 'to subject,' similar to the idea of a leader ruling over his subjects (exercising authority over them). The idea of God placing mankind on earth to 'rule over' it is found clearly in the Qur'an. 
When your Lord told the angels, 'I will make a regent on earth,' they said, 'Will you put someone there who will cause destruction on it and shed blood, while we glorify, praise, and sanctify you?' He said, 'I know things you do not know.' (Quran, Al-Baqarah 2:30)

The translator of Al-Baqarah 2:30 notes the following regarding the word translated as 'regent'

The word in Arabic is /khalifah/, sometimes translated vicegerent. It is used for caliph and comes from the root 'to be behind or after.' Only Adam (here) and David (28:26) are named as regents in the Qur'an. In 7:69,73 and 27:62 people are called regents on the earth. (The Arabic-English Reference Qur'an, 2013).

A definition for the word regent is 'a person who governs a kingdom in the minority, absence, or disability of the sovereign' (Merriam-Webster Online Dictionary, 2013). What this seems to suggest is that God is placing humankind as rulers over the earth, but without relinquishing His right as absolute sovereign. In essence, humankind are God's 'regents' on earth, but are still 'behind or after' him in terms of absolute authority.

In the account of the creation of man from Genesis, we read the following:

The Lord God took the man and placed him in the orchard in Eden to care for it and to maintain it. (Tanakh, Genesis 2:15)

Here, the Genesis account again suggests that man is created by God as a caretaker (see also Harrison (2006)).

The idea of God being the sovereign who gives control over his 'property' to humans as regents for a short time is reinforced in New Testament parables. One instance is within the context of a master putting his servants in charge of his property while he is 'on a journey' (New Testament, Matthew 25:14-30). Another similar instance is within the context of a garden or land owner that leases or lends the property to a third-party grower, again while he is 'on a journey.' (New Testament, Mark 12:1-9). In both cases, the owner temporarily puts his property in the hands of others for their use, provision, and control. However, in both cases the master of the property demands an accounting for what has been done with his property while he is 'away.'

Additional verses in the Qur'an clearly identify mankind as regents. The following two verses make clear that the authority of the regents is over the creation or the Earth.

Do you like it that a reminder has come from your Lord to a man from among you to warn you? Remember when he made you regents after Noah's people, and he increased your stature among the creation, so remember Allah's benefits so that you may prosper. (Qur'an, Al-A'raf 7:69)

Who answers the one in need when he prays to him, keeps evil away, and makes them regents over the earth? Is there another god besides Allah? They remember infrequently. (Qur'an, An-Naml 27:62)

The idea of the Earth being under man's control by the permission of God is again reinforced in the Psalms. 
You [God] grant mankind honor and majesty; you appoint them to rule over your creation; you have placed everything under their authority. (Tanakh, Psalms 8:6)

On the subject of being a regent, it is interesting to note that the Qur'an has the following to add regarding instructions given to King David.

David, we have made you a regent on earth, so judge truthfully among men and don't follow passion, or it will lead you astray from Allah's path. Those who are led astray from Allah's path will have severe torment on the day of reckoning because of what they forgot. (Qur'an, Sād 38:26)

From an environmental perspective, passion may include lusts for things (money, possessions, certain foods, etc.) that have the potential to cause an overall degradation of the environment. Humans as regents are to 'not follow passion' in their rule over the Earth and should remember that they are ruling by God's leave. In present governmental situations, leaders are considered tyrants if they only use their subjects for their own gain, caring nothing about who or what is destroyed as they seek to maximize their own personal comfort and advancement. The best leaders are those who look out for, protect, and seek the best for their subjects, all the while enjoying the benefits of their position as leaders. It seems only logical to apply the same principles of good leadership to our treatment of the earth that we apply to leadership of human subjects.

So, another 'common word' among monotheists could be stated like this: 'Humans are regents of God in their rule over the earth and should act as righteous rulers in their treatment of nature.'

\section{Humans should not waste}

In a 2013 report on the food wastage footprint, the United Nations Food and Agricultural Organization (FAO) estimated that about one-third (1/3) of all food produced is wasted rather than consumed (FAO, 2013). Globally estimated amounts of surface and groundwater consumed by wasted food is a staggering $250 \mathrm{~km}^{3}$ (FAO, 2013). In irrigated agriculture, reports of irrigation efficiency around the globe vary widely (Jensen, 2007), and overall average irrigation efficiency may be as low as $40 \%$ (i.e., $60 \%$ of water applied is not 'used' by the plants) (Walker, 2003). When these two numbers are put together (food waste plus application waste), an estimated ratio of water applied that is necessary for production of consumed food globally may be as low as $27 \%$ ( 0.67 consumed ratio multiplied by 0.40 irrigation efficiency ratio). Food and water are clearly connected in the Qur'an by the following verse:

Let man look at his food. We poured out water, split the earth, and caused seeds to sprout in it, as well as grapes, clover, olives, palms, thick gardens, fruit and plants, as enjoyment for you and your cattle. (Qur'an, Abasa 80:24-32)

Within this context, the monotheistic scriptures give clear guidance regarding daily practices of consumption. In the Qur'an, we find the following:

Children of Adam, take your apparel at every place of worship, eat and drink, but do not waste. He does not love the wasteful. (Qur'an, Al-A'raf 7:31) 
He planted trellised and untrellised gardens, palm trees, and differing plants for food: olives, pomegranates, similar yet dissimilar. Eat their fruit when it ripens, and pay for it on harvest day. Do not waste it. He does not love wasters. (Qur'an, Al-An`am 6:141)

These verses are clear: don't be wasteful with what you consume! However, those who would seek to apply this command will be required to be diligent and disciplined. In the Tanakh, we read the following:

The one who neglects discipline ends up in poverty and shame, but the one who accepts reproof is honored. (Tanakh, Proverbs 13:18)

Although not specifically applied within the arena of natural resource management, there are numerous texts in the New Testament that fit well within the context of 'not wasting.' In the well-known story of the 'prodigal son', a man asks for his share of his inheritance before his father has died (New Testament, Luke 15:11-14). His father agrees, and the son leaves to squander (waste) all that he has been given in a short amount of time. The result of his action is poverty; he is no longer able to support himself because of the wasteful use of his resources.

After Jesus miraculously feeds over five thousand people using only five barley loaves and two fish, he gives the following instructions:

When they were all satisfied, Jesus said to his disciples, 'Gather up the broken pieces that are left over, so that nothing is wasted.' (New Testament, John 6:12)

Why would Jesus care that 'nothing be wasted' after he has (through a miracle) fed such a large number of people? Even in this case, it is clear that humans should not waste, even if a provision has been miraculously supplied. Such miracle events should be regarded as rare, certainly not within the context of what is provided from nature.

In another place in the New Testament, we read the following:

So put away all filth and evil excess and humbly welcome the message implanted within you, which is able to save your souls. (New Testament, James 1:21)

Confirmed in the Qur'an, the following verse deals specifically with excess in consumption

Eat the good things we have provided you and do not transgress in them, or my anger will come upon you. If my anger comes upon anyone, he will fall. (Qur'an, Ta Ha 20:81)

The part of the verse translated 'do not transgress in them' has also been translated by others as 'commit no excess therein.' The 'story of the two men' found in the Quran exemplifies divine punishment or trial in the form of local fresh water resources disappearing, leading to the collapse of local production agriculture. The catastrophe takes place as a result of the ungratefulness and arrogance in relationship to the resources a man was allocated by God (Qur'an, Al-Kahaf 18:32-44). However, we should not think that only the individuals who transgress will face trials like this. Of special note related to community vs. individual consumption is the following: 
Fear a trial that will not afflict only the wicked among you. Know that Allah is severe in punishment. (Qur'an, Al-Anfal 8:25)

Just because individual persons are not wasters or given to excess does not mean they will not share in the fate of the wasteful. Therefore, it is important to approach the subject of environmental or water management related to waste and misuse from a community and global as well as an individual perspective. We all share the same planet; waste or misuse by a few will in the long run affect us all. This is a key principle in 'commons' resource management that applies to all resources that are shared by a population pool (Hardin, 1968).

This is another point upon which monotheists can agree and work toward applying in the area of water and agricultural management: humans should not waste or be given to excess in their use of natural resources. In the context of agricultural water use, we should work toward efficiency (i.e., not wasting or applying excess) when we apply limited natural resources such as extracted fresh water for irrigation and when we seek to distribute and consume what has been produced.

\section{Water ownership rights and the sale of fresh water}

In the Tanakh, we see that nations and individuals had rights to their water and had the ability to buy and sell such water. When the descendants of Israel (also known as Jacob, the son of Isaac) left Egypt during the exodus, they initially had no land or water under their direct ownership and supervision. As they approached the land belonging to the descendants of Esau (Jacob's brother), they were given the following instructions:

Instruct these people as follows: 'You are about to cross the border of your relatives the descendants of Esau, who inhabit Seir. They will be afraid of you, so watch yourselves carefully. Do not be hostile toward them, because I am not giving you any of their land, not even a footprint, for I have given Mount Seir as an inheritance for Esau. You may purchase food to eat and water to drink from them. All along the way I, the Lord your God, have blessed your every effort. I have been attentive to your travels through this great wasteland. These forty years I have been with you; you have lacked for nothing.' (Tanakh, Deuteronomy 2:4-7)

As the descendants of Israel approach the land of Esau's descendants (Edom), they send the following message to the Edomites

Please let us pass through your country. We will not pass through the fields or through the vineyards, nor will we drink water from any well. We will go by the King's Highway; we will not turn to the right or the left until we have passed through your region.... Then the Israelites said to him, 'We will go along the highway, and if we or our cattle drink any of your water, we will pay for it. We will only pass through on our feet, without doing anything else.' (Tanakh, Numbers 20:17, 19)

Moses, as the leader of the people, applied the same approach in his dealings with the King of Heshbon. 
Then I sent messengers from the Kedemoth Desert to King Sihon of Heshbon with an offer of peace: 'Let me pass through your land; I will keep strictly to the roadway. I will not turn aside to the right or the left. Sell me food for cash so that I can eat and sell me water to drink. Just allow me to go through on foot, just as the descendants of Esau who live at Seir and the Moabites who live in Ar did for me, until I cross the Jordan to the land the Lord our God is giving us.' (Tanakh, Deuteronomy 2:26-29)

What can be seen from these scriptures is that nations had rights to the water resources within their boundaries. In addition, we see that water can be bought and sold, despite the fact that it is a natural resource and is considered by some to be a basic human right. Especially of note in this context is that the descendants of Israel were aided supernaturally in numerous ways up to this point along their journey from Egypt (parting of the sea, manna from heaven, water from a rock, etc.). In spite of this fact, God still commanded them to 'purchase food to eat and water to drink.' It is clear that God could have supernaturally provided water for consumption again. Instead, the people are told to purchase water from others. Moses (the leader of the people) applies this guideline in his communications with both the Edomites and with Heshbon.

Although water ownership is not clearly discussed in the New Testament or Qur'an, both books have a clear endorsement of the principles laid down in the Tanakh (New Testament, Matthew 5:17; Qur'an, Al-Ma'idah 5:44, 46, Al-‘Ankabut 29:46).

Do not think that I [Jesus] have come to abolish the law or the prophets [Tanakh]. I have not come to abolish these things but to fulfill them. (New Testament, Matthew 5:17)

We [God] revealed the Tawrah, in which is guidance and light. The prophets who submitted, the rabbis, and the priests judge the Jews according to the portion of Allah's book with which they have been entrusted. They were witnesses of it. So do not fear people, but fear me, and do not sell my verses for a small price. Whoever does not judge by what Allah has revealed are disbelievers. (Qur'an, Al-Ma'idah 5:44)

We made Isa [Jesus] son of Mariam follow in their footsteps, confirming the Tawrah [Tanakh] in his possession, and we gave him the Injil [Gospel], in which is guidance and light, confirming the Tawrah in his possession, as guidance and an admonition to the godly. (Qur'an, Al-Ma'idah 5:46)

Do not argue with the people of the book but [speak] in a fair manner, except with the wicked among them. Say, 'We believe in what was revealed to us and what was revealed to you. Our god and your god is one, and we submit to him.' (Qur'an, Al-'Ankabut 29:46)

The guidance that can be gleaned from these texts is: private entities (individuals, communities, and nations) have the right to exercise control over sources of fresh water. Fresh water can be bought and sold among these parties within the context of proper management of the resource (e.g., no excess use, no contamination, etc.).

\section{Water rights disputes}

Disputes over water rights are common in the world today. Increased population, higher standards of living, and modern agricultural practices have all contributed to a greater stress on fresh water resources 
than in past generations. In spite of the modern situation, we can see from the scriptures that disputes over water rights are not exclusive to our generation. Abraham and Isaac both had disputes over water with their neighbors. In the Tanakh we read

But Abraham lodged a complaint against Abimelech concerning a well that Abimelech's servants had seized. 'I do not know who has done this thing,' Abimelech replied. 'Moreover, you did not tell me. I did not hear about it until today.' Abraham took some sheep and cattle and gave them to Abimelech. The two of them made a treaty. Then Abraham set seven ewe lambs apart from the flock by themselves. Abimelech asked Abraham, 'What is the meaning of these seven ewe lambs that you have set apart?' He replied, 'You must take these seven ewe lambs from my hand as legal proof that I dug this well.' (Tanakh, Genesis 21:25-30)

In this account, we see that the water rights dispute was settled via negotiations that culminated in a treaty between the two parties. This path toward resolving water rights disputes (negotiations and/or treaties) is practiced widely among countries or states using treaties or legal settlements without resort to violent confrontation.

In another account, this one involving Abraham's son Isaac and a second party with the name of Gerar, we see that the final resolution was to move on to another water source.

When Isaac's servants dug in the valley and discovered a well with fresh flowing water there, the herdsmen of Gerar quarreled with Isaac's herdsmen, saying, 'The water belongs to us!' So Isaac named the well Esek because they argued with him about it. His servants dug another well, but they quarreled over it too, so Isaac named it Sitnah. Then he moved away from there and dug another well. They did not quarrel over it, so Isaac named it Rehoboth, saying, 'For now the Lord has made room for us, and we will prosper in the land.' (Tanakh, Genesis 26:19-22)

Unlike Abraham and Abimelech, the party of Isaac and the party of Gerar could not come to an agreement concerning who owned the water. Rather than continuing to argue or resorting to physical means (war) to solve the dispute, Isaac simply moved on to another source of fresh water that was not disputed. In the modern sense, this could perhaps be compared with nations who choose desalination above going to war over existing fresh water resources. It could also perhaps be compared with the establishment of agreed upon 'buffer zones' in groundwater extraction. These buffer zones are established so that parties who share an aquifer are no longer concerned about their share of water being mined by others.

The scriptures instruct individuals and nations to use the water resources within their own possession rather than taking from others.

Drink water from your own cistern and running water from your own well. (Tanakh, Proverbs 5:15)

The command to use one's own resources does not, however, preclude a righteous person from 'loving the neighbor,' as can be seen from other verses in Proverbs.

A generous person will be enriched, and the one who provides water for others will himself be satisfied. (Tanakh, Proverbs 11:25) 
If your enemy is hungry, give him food to eat, and if he is thirsty, give him water to drink... (Tanakh, Proverbs 25:21)

Again, the New Testament and Qur'an clearly affirm the principles given in the Tanakh (New Testament, Matthew 5:17; Qur'an, Al-Ma'idah 5:44, 48, Al-'Ankabut 29:46). Therefore, a conclusion can be drawn that some examples of how to solve water rights disputes can be derived from the Tanakh.

The fundamental concept to achieve consensus from these verses is that there are multiple solutions to disputes over water. Such solutions may include dialog, treaties, and certain parties 'changing location' to use other sources of fresh water. In all cases, individual parties are expected to use what has been given to them rather than taking what belongs to someone else. Over and above this, individual parties are expected to be generous toward others (including even enemies) with what resources they have been given.

\section{Construction of water works for water supply, control of contamination, and sharing resources}

In modern agriculture, water is supplied through natural (rain) and man-made means (irrigation). Irrigation supply water is most often taken from either fresh surface waters or groundwater reserves.

The Qur'an recounts how God sends water for agriculture and made the rivers (water) subject to man's control.

Allah is the creator of the heavens and the earth, and he sent down rain from the sky, brought forth fruits from it as provision for you, and made ships subject to you so they can travel on the sea by his command, and he made the rivers subject to you. (Qur'an, Ibrahim 14:32)

In the Tanakh and Qur'an, we see specifically how two kings, the first Solomon and the second Hezekiah, applied this principle of subjecting waters to their control for meeting water supply needs (Tanakh, Ecclesiastes 2:6, 2 Chronicles 32:30; Qur'an, Saba' 34:13a). It is important to note that both of these kings were considered righteous and good by the monotheistic scriptures; therefore, it can be assumed that the water projects undertaken by these kings were also considered righteous and good.

I [Solomon] constructed pools of water for myself, to irrigate my grove of flourishing trees. (Tanakh, Ecclesiastes 2:6)

They made what he [Solomon] willed for him: holy places, statues, large dishes like cisterns [also translated as 'aqueducts'], and fixed pots....(Qur'an, Saba' 34:13a)

Hezekiah dammed up the source of the waters of the Upper Gihon and directed them down to the west side of the City of David [Jerusalem]. Hezekiah succeeded in all that he did. (Tanakh,2 Chronicles 32:30)

Solomon's construction of water works for irrigation was most likely using water captured from the Gihon spring, an intermittent spring and the primary water source for the city of Jerusalem during that period. The first use of groundwater/springs for 'watering the earth' is recorded in Genesis during the creation account. 
Springs would well up from the earth and water the whole surface of the ground. (Tanakh, Genesis 2:6)

The construction of wells for the extraction of groundwater was performed by both Abraham and Isaac (Tanakh, Genesis 26:18, 25, 32-33).

Isaac reopened the wells that had been dug back in the days of his father Abraham, for the Philistines had stopped them up after Abraham died. Isaac gave these wells the same names his father had given them. (Tanakh, Genesis 26:18)

Then Isaac built an altar there and worshiped the Lord. He pitched his tent there, and his servants dug a well... That day Isaac's servants came and told him about the well they had dug. 'We've found water,' they reported. So he named it Shibah; that is why the name of the city has been Beer Sheba to this day. (Tanakh, Genesis 26: 25, 32-33)

Water quality is of importance for both domestic consumption and agriculture. Water purification is mentioned in the monotheistic texts in the context of water treatment miracles (performed by Moses and Elisha) and natural processes (the water cycle).

Then they came to Marah, but they were not able to drink the waters of Marah, because they were bitter. (That is why its name was Marah.) So the people murmured against Moses, saying, 'What can we drink?' He cried out to the Lord, and the Lord showed him a tree. When Moses threw it into the water, the water became safe to drink. (Tanakh, Exodus 15:23-25a)

The men of the city said to Elisha, 'Look, the city has a good location, as our master can see. But the water is bad and the land doesn't produce crops.' Elisha said, 'Get me a new jar and put some salt in it.' So they got it. He went out to the spring and threw the salt in. Then he said, 'This is what the Lord says, 'I have purified this water. It will no longer cause death or fail to produce crops." The water has been pure to this very day, just as Elisha prophesied. (Tanakh, 2 Kings 2:19-22)

He sent the winds as good news before his mercy. We sent pure rain ['pure water' in Qur' anic Arabic] down from the sky, to revive a dead town and we irrigate with it many cattle and people we have created. We distributed it among them so they would remember, and they refused. Most people are ungrateful. (Qur'an, Al-Furqan 25:48-50)

The 'common word' for monotheists in this case could probably be written as follows: construction of water works for distribution, storage, and/or purification of water is a good and acceptable practice for meeting human consumption and agricultural needs.

\section{Conclusions: a scripture-based consensus can lead to unified water management solutions covering a variety of issues and disputes}

Monotheists have much in common regarding approaches to water and its management. The fundamental scriptures of the monotheistic faiths are in agreement on many basic principles upon which water management plans and strategies can be built. A summary of these basic principles is as follows: 
The value of water:

1. The scriptures are in agreement regarding the value of water as the first matter to exist and of the fact that God was the first one to separate and exercise control over water.

2. Water has an intrinsically spiritual value and is a sign reminding humans of spiritual realities that are beyond the physical world.

3. One of the roles of water as provided by God is for production agriculture. Water is given by God to produce provisions for man in the form of food.

The human's role in relation to water

4. Humans are assigned to be regents of God in their rule over the earth and should act as righteous rulers in their treatment of nature, including water.

Practical water management implications

5. Humans should not waste or be given to excess in their use of natural resources. In the context of agricultural water use, humans should work towards efficiency (i.e., not wasting or applying excess) when applying limited natural resources such as extracted fresh water for irrigation and when seeking to distribute and consume what has been produced.

6. Private entities (individuals, communities, and nations) have the right to exercise control over sources of fresh water within their allotted domain. Fresh water can be bought and sold among these parties.

7. There are multiple solutions to disputes over water. Such solutions may include dialog, treaties, and certain parties moving on to other sources of fresh water. In all cases, individual parties are expected to use what has been given to them rather than taking what belongs to others. Over and above this, individual parties are expected to be generous towards and show love for others (including even enemies) with what resources they have been given.

8. Construction of water works for distribution, storage, and/or purification of water is a good and acceptable practice for meeting human consumption and agricultural needs.

This research is not intended to be exhaustive in its search for 'common words' within the monotheistic scriptures related to water management. Rather, it is intended to lay the foundations for continued research and dialog among monotheists who have a shared God (the God of Abraham) and common themes within the sacred texts. The advantage of this approach is its broad appeal for all monotheists, regardless of their religion or sect, to come to common ground on water management.

Perhaps the fundamental questions of 'so what' or 'why is this relevant' or 'where is this relevant' should be addressed. There are at least three areas of application of 'common ground' monotheistic cooperation that must be considered in water management. First, the issue of the acceptability of using treated wastewater for drinking and other purposes (either directly or indirectly), which has considerable religious overtones, particularly within Islam (IslamQA, 2014). Less than 10\% of treated wastewater is currently reused in the Middle East region. Secondly, conservation of water within the context of agricultural use is a critical issue in accommodation of future population growth and to meet water management goals related to fundamental human rights (Gleick, 1999). Multiple monotheistic religions coexist in over 40 countries today, and with population migration, the number will greatly increase in the future. Thirdly, many large transboundary river and groundwater systems are shared by monotheistic cultures (e.g., the Nile River and the Nubian Sandstone Aquifer). People of multiple monotheistic faiths share water resources in areas having water disputes that have contributed to violent confrontations or war (e.g., Palestine and Israel) (Hillel, 1994; Wolf, 1995). 
Diplomats and teams of water management professionals that assist in development of local and regional water management plans and policies in areas of the globe occupied by monotheists need to be aware of the 'common ground' religious doctrines that unify rather than divide populations. These principles can be incorporated into water policies and management plans to allow them to receive a higher degree of acceptance. It is hoped that the principles outlined above will provide motivation and be applied as guidance for monotheists worldwide in individual, community, national, and international decisions related to the management and use of water.

\section{References}

Abderrahman, W. A. (2000). Application of Islamic legal principles for advanced water management. Water International 25 (4), 513-518.

Al-Kharouf, S., Al-Khatib, I. A. \& Shaheen, H. Q. (2008). Appraisal of social and cultural factors affecting wastewater reuse in the West Bank. International Journal of Environment and Pollution 33(1), 3-14.

Al-Weshah, R. A. (2000). Optimal use of irrigation water in the Jordan Valley: a case study. Water Resources Management 14 (5), 327-338.

Amery, H. A. (2001). Islamic water management. Water International 26(4), 481-489.

Bin Muhammad, G., Shah-Kazemi, R. \& Ahmed, A. (2010). The Holy Qur'an and the environment. Paper presented at the Royal Aal Al-Bayt Institute for Islamic Thought Environment Symposium, Amman, Jordan.

Brown, Driver, Briggs. The New American Standard Old Testament Hebrew Lexicon Hebrew Lexicon entry for Kabash. Online lexicon adapted from Brown, Driver,, Briggs (1906). A Hebrew and English Lexicon of the Old Testament. Clarendon Press, Oxford. Retrieved from http://www.biblestudytools.com/lexicons/hebrew/nas/kabash.html.

Burmil, S., Daniel, T. C. \& Hetherington, J. D. (1999). Human values and perceptions of water in arid landscapes. Landscape and Urban Planning 44(2-3), 99-109. doi: 10.1016/S0169-2046(99)00007-9.

Central Intelligence Agency of the United States (CIA) (2013). The world factbook. Retrieved November 20, 2013, from https://www.cia.gov/library/publications/the-world-factbook/geos/xx.htm.

Chuvieco, E. (2012). Religious approaches to water management and environmental conservation. Water Policy 14(S1), 9. doi: $10.2166 /$ wp.2012.000.

Coward, H. (2003). Ethics and nature in the world's religions. Environment across Cultures 19, 91-109.

Faruqui, N. I., Biwas, A. K. \& Bino, M. J. (eds) (2001). Water Management in Islam. Water Resources Management and Policy. United Nations University Press, New York.

Food, Agricultural Organization of the United Nations (FAO) (2013). Food Wastage Footprint Impact on Natural Resources Summary Report. Food and Agricultural Organization of the United Nations. Retrieved from http://www.fao.org/docrep/018/ i3347e/i3347e.pdf.

Gleick, P. (1999). The human right to water. Water Policy 1(5), 487-503.

Haddad, M. (2012). An Islamic perspective on food security management. Water Policy 14, 121-135. doi: 10.2166/Wp.2012. 006.

Hardin, G. (1968). The tragedy of the commons. Science 162, 1243-1248.

Harrison, P. (2006). Having dominion: Genesis and the mastery of nature. In Environmental Stewardship. Berry, R. J. (ed.). T\&T Clark International, London, pp. 17-31.

Hillel, D. (1994). Rivers of Eden: The Struggle for Water and the Quest for Peace in the Middle East. Oxford University Press, Oxford.

Hillel, D. (2005). The Natural History of the Bible: An Environmental Exploration of the Hebrew Scriptures. Columbia University Press.

Islam Question, Answer (IslamQA) (2014). 130898: Ruling on using waste water after purifying it by modern means. Retrieved 19 November 2014 from http://islamqa.info/en/130898.

Jensen, M. E. (2007). Beyond irrigation efficiency. Irrigation Science 25(3), 233-245. doi: 10.1007/s00271-007-0060-5.

King Abdullah Bin Abdulaziz International Centre For Interreligious, Intercultural Dialogue (KAICIID) (2012). Journey to KAICIID. King Abdullah Bin Abdulaziz International Centre For Interreligious and Intercultural Dialogue, Vienna, Austria. 
Lipchin, C. (2007a). A future for the Dead Sea basin: water culture among Israelis, Palestinians and Jordanians. Water Resources in the Middle East 2, 87-107. doi: 10.1007/978-3-540-69509-7_9.

Lipchin, C. (2007b). Water, agriculture and zionism: exploring the interface between policy and ideology. In Integrated Water Resources Management and Security in the Middle East. Springer-Verlag New York Inc, pp. 251-267.

Maliva, R. G. \& Missimer, T. M. (2012). Religious and cultural influences on water management. In Arid Lands Water Evaluation and Management. Maliva, R. G. \& Missimer, T. M. (eds). Springer, Berlin Heidelberg, pp. 871-879.

Mattson, I. (2010). The Islamic View on Consumption and material development in light of Environmental Pollution. Paper presented at the The Royal Aal Al-Bayt Institute for Islamic Thought Environment Symposium, Amman, Jordan.

Merriam-Webster Online Dictionary (2013). Retrieved from www.merriam-webster.com.

Mieth, D. (2010). Christian Conceptions of Creation, Environmental Ethics, and the Ecological Challenge Today. Paper presented at the The Royal Aal Al-Bayt Institute for Islamic Thought Environment Symposium, Amman, Jordan.

Naff, T. \& Dellapenna, J. (2002). Can there be confluence? A comparative consideration of Western and Islamic fresh water law. Water Policy 4(6), 465-489. doi: http://dx.doi.org/10.1016/S1366-7017(02)00041-7.

NET Bible ${ }^{\circledR}$ 1996-2006. Retrieved from http://netbible.org.

Pimentel, D., Berger, B., Filiberto, D., Newton, M., Wolfe, B., Karabinakis, E., Clark, S., Poon, E., Abbett, E. \& Nandagopal, S. (2004). Water resources: agricultural and environmental issues. Bioscience 54(10), 909-918.

Priscoli, J. D. (2012). Reflections on the nexus of politics, ethics, religion and contemporary water resources decisions. Water Policy 14(S1), 21. doi: 10.2166/wp.2012.002.

The Arabic-English Reference Qur'an. (2013). First edn. The Reference Qur'an Council. www.referencequran.com

The Makkah Declaration (2008). Paper produced at the The World Islamic Conference on Dialogue, Makkah, Kingdom of Saudi Arabia. http://www.kaiciid.org/en/the-centre/declarations/the-makkah-declaration-kopie.html.

The Royal Aal al-Bayt Institute for Islamic Thought, J. (2007). A common word between us and you. Retrieved 29 November 2013, from www.acommonword.com.

Saleh, W. A. (2008). A fifteenth-century Muslim Hebraist: Al-Biqā’'ì and his defense of using the Bible to interpret the Qur'ān. Speculum 83(03), 629-654. doi: 10.1017/S0038713400014615.

Siler, C. (2008). Water Management in Monotheistic Religions: Water Management Practices and Motivation Among the World's Three Predominant Monotheistic Religions-Christianity, Islam, and Judaism-with an Emphasis on Islam. CE 397-Transboundary Water Resources. University of Texas.

Walker, W. R. (2003). Surface Irrigation Simulation, Evaluation and Design. Utah State University.

Wolf, A. (1995). Hydropolitics along the Jordan River; Scarce Water and Its Impact on the Arab-Israeli Conflict. United Nations University Press.

Wolf, A. (2012). Spiritual understandings of conflict and transformation and their contribution to water dialogue. Water Policy 14(S1), 73. doi: 10.2166/wp.2012.010.

Received 16 August 2014; accepted in revised form 18 January 2015. Available online 13 March 2015 